\title{
Investigation of the organelle pathology of skeletal muscle in chronic alcoholism
}

\author{
FC MARTIN, * G SLAVIN, † AJ LEVI, $\ddagger$ TJ PETERS* \\ From the Divisions of *Clinical Cell Biology and $\ddagger$ Clinical Sciences and the $†$ Section of Histopathology, MRC \\ Clinical Research Centre, Harrow, Middlesex
}

SUMMARY The muscle abnormalities associated with chronic alcohol consumption were studied by applying histological and biochemical techniques to tissue obtained by percutaneous needle biopsy from the quadriceps muscles of 41 patients. Measurement of the fibre size showed atrophy of both type I $(p<0.05)$ and type II $(p<0.001)$ fibres. The degree of atrophy was more severe for type II fibres (33\% reduction in median diameter) than type I (17\%). Marker enzyme activities for the principal organelles were assayed. Compared with biopsy specimens from nonalcoholic controls, no differences were found in the activities of lysosomal, mitochondrial, peroxisomal, cytosolic, sarcolemmal, or sarcoplasmic reticulum enzymes, expressed per $\mu \mathrm{g}$ DNA. A reduction in the protein to DNA ratio was evident in severely atrophic biopsies, and this was associated with a significant reduction of myofibrillary $\mathrm{Ca}^{2+}$-ATPase activity. These results suggest a selective loss of type II fibre myofibrillary protein and do not confirm earlier suggestions of specific mitochondrial damage.

Recent years have seen a considerable increase in alcohol consumption in most countries throughout Europe. This has been accompanied by an increased incidence of alcohol-related physical disease, ${ }^{\prime}$ which now accounts for a substantial proportion of medical illness seen in urban hospitals. ${ }^{23}$ Work on primates, including man, ${ }^{4}$ has shown that ethanol, even with a nutritionally adequate diet, causes the fatty change characteristically seen in the livers of heavy drinkers. Skeletal muscle damage in alcoholism was first described as long ago as $1822,{ }^{5}$ but it has only recently become the attention of detailed investigation. Recent reviews have developed the clinicopathological classification and discussed possible mechanisms of damage. ${ }^{6-9}$ Acute rhabdomyolysis and chronic symmetrical proximal wasting are quite distinct clinical pictures seen in alcoholics, but some of the ultrastructural and biochemical reports have not clearly distinguished between these two syndromes.

Ultrastructural changes in the mitochondria, ${ }^{10-16}$ sarcoplasmic reticulum, ${ }^{16}$ and sarcolemma ${ }^{17}$ have been reported after acute or chronic exposure to ethanol, but these studies were only qualitative and functional abnormalities in these organelles have not been studied systematically. Some reports ${ }^{18} 19$ have suggested that there is reduced activity of suc-

Accepted for publication 7 December 1983 cinate and malate dehydrogenases and of cytochrome c oxidase in muscle from heavy drinkers, also implicating mitochondrial damage in this disorder.

This study has differentiated the acute and chronic forms of muscle damage with a view to investigating possible differences in organelle pathology. The investigation of tissue organelles by enzyme analysis of milligram quantities of tissue has proved valuable in the understanding of various human diseases. ${ }^{20}$ It has been used to study human $^{2122}$ and experimental ${ }^{23}$ cardiomyopathies and muscular dystrophy in the mouse. ${ }^{24}$ The properties of the principal organelles have recently been studied in normal human muscle ${ }^{25}$ assay methods and specific assay conditions have been established for the organelle marker enzymes.

This paper describes the application of these techniques to the study of muscle damage associated with alcoholism. To allow correlation between morphological and biochemical data, muscle biopsies have been classified as showing acute damage or chronic fibre atrophy, and the latter has been quantified.

\section{Material and methods}

PATIENTS

Needle biopsies were obtained with a modified 448 
Bergström needle from the vastus lateralis portion of the quadriceps muscle by a standard technique. ${ }^{26}$ Control biopsies were taken from hospital patients by the same technique, as part of an investigation of muscle or systemic symptoms unrelated to alcohol. Full clinical and laboratory investigation subsequently showed these control patients to have no evidence of muscle disease; their biopsies were histologically normal. Muscle biopsies were taken from a consecutive series of patients receiving treatment for physical of psychological problems associated with the consumption of more than $100 \mathrm{~g}$ (men) or $80 \mathrm{~g}$ (women) of ethanol daily for at least three years. All patients were studied between one and five days after admission. A few patients were excluded from the study because deranged clotting function made biopsy unsafe. All patients were euthyroid by routine laboratory tests. Most had mildly deranged liver function and macrocytosis, but those with biochemical evidence of osteomalacia or seriously disturbed liver function as reflected by a serum albumin concentration below $25 \mathrm{~g} / \mathrm{l}$ were excluded from analysis. No patient had the clinical picture of pseudo-Cushing's syndrome

\section{PROCESSING OF BIOPSIES}

About $30-60 \mathrm{mg}$ of tissue was obtained and divided immediately. One portion was taken for histological study, which included standard histological stains ${ }^{17}$ to identify inflammation and acute myopathy and a stain for myosin ATPase at $\mathrm{pH} 9.4$ to distinguish fibre types. The size of fibre types I and II was estimated using a "Magiscan" image analysis system. ${ }^{27}$ Separate microscope fields were studied to allow measurement of 150 fibres of each type per specimen (Fig. 1). A median diameter and an atrophy factor $^{28}$ were calculated for each fibre type. The atrophy factor provides a numerical assessment of the size of the tail of small fibres in a histogram constructed of individual fibre diameter measure-

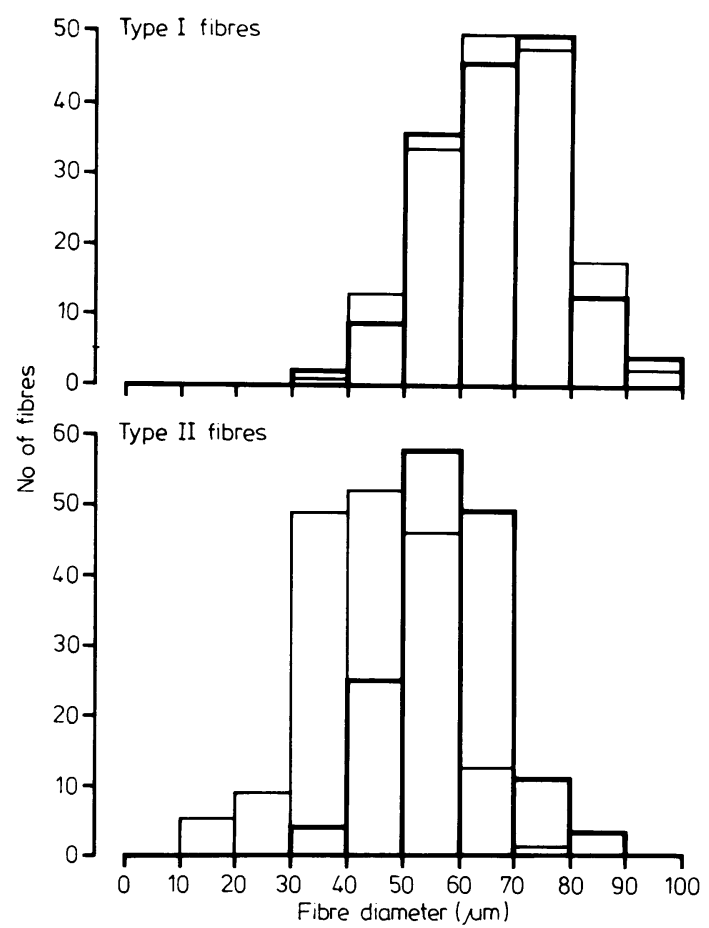

Fig. 2 Histograms constructed from individual fibre diameter measurements of 150 fibres. Normal male control (-) male alcoholic (-).

ments (Fig. 2). The criteria for determining the presence of acute myopathy were characteristic features of an acute rhabdomyolysis. ${ }^{24}$ The biopsies were then subdivided into five groups: normal patient controls; alcoholic "normal,"-that is, with normal histological appearances and morphometry; alcoholic with acute myopathy; alcoholic with mild type II fibre atrophy; alcoholic with severe type II

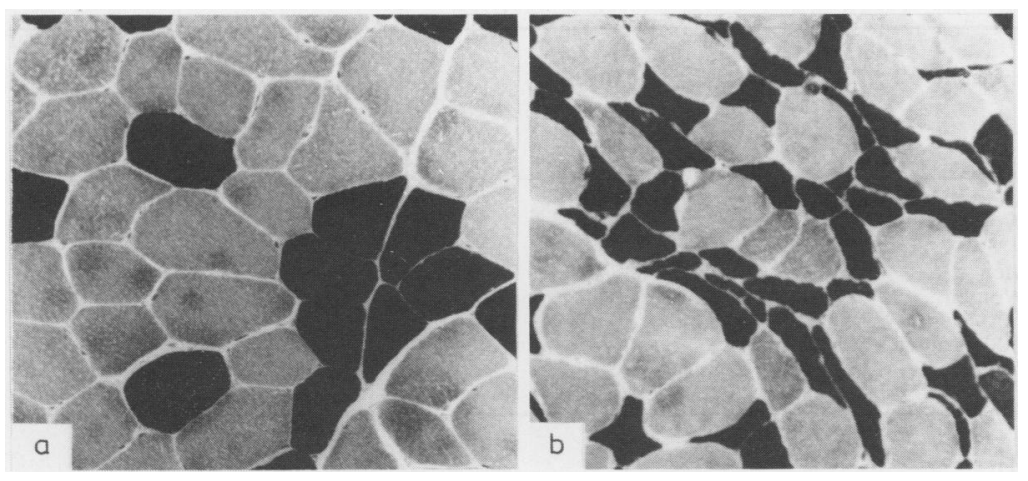

Fig. 1 Photomicrograph of myosin ATPase (pH 9.4) stained section of muscle biopsy taken from (a) a normal male control and (b) a male alcoholic showing atrophy of type II (dark staining) fibres. 
atrophy. The group of biopsies showing acute myopathy was excluded from the statistical analysis because of the small number and is discussed separately.

\section{BIOCHEMICAL ANALYSIS}

The portion of the biopsy for tissue biochemical analysis was collected into $3 \mathrm{ml}$ ice cold $0.25 \mathrm{~mol} / \mathrm{l}$ sucrose solution containing $20 \mathrm{mmol} / \mathrm{l}$ ethanol and $1 \mathrm{mmol} / \mathrm{l}$ disodium EDTA, $\mathrm{pH} 7.4$ (sucrose medium). The sample was then stored at $-20^{\circ} \mathrm{C}$ for up to eight weeks before homogenisation. After it had thawed, the sample was minced with fine scissors and then further disrupted with a small Polytron homogeniser (Kinematica GmbH, Lucerne, Switzerland) at setting no 2 for $15 \mathrm{~s}$. Homogenisation was then performed with 10 strokes of a loosefitting (type A) glass pestle in a small Dounce homogeniser (Kontes Glass Co, Vineland, New Jersey, USA) followed by eight strokes of a tightfitting (type B) pestle. These procedures were performed in ice. The homogenate was then filtered through a $50 \mu \mathrm{m}$ nylon mesh which removes fibrous debris. ${ }^{30}$ Enzyme assays were performed within two weeks of homogenisation and the homogenate was stored at $-20^{\circ} \mathrm{C}$ between analyses; samples were not refrozen and thawed more than twice.

\section{ENZYMIC ANALYSES}

These were based on fluorimetric or spectrophotometric methods previously adapted for human skeletal muscle biopsies and for which the optimum assay conditions have been determined and enzyme localisations established after subcellular fractionation by sucrose density gradient centrifugation. ${ }^{25}$ Protein was measured by a modification $^{31}$ of the method of Lowry, ${ }^{32}$ with bovine serum albumin as standard. DNA was measured fluorimetrically ${ }^{33}$ with calf thymus (Sigma type I) as standard.

\section{ANALYSIS OF RESULTS}

Means and standard deviations were calculated for each of the groups for each enzyme activity in terms of milliunits $/ \mathrm{mg}$ protein and milliunits $/ \mu \mathrm{g}$ DNA, where 1 milliunit is the amount of enzyme activity producing one nmol of reaction product at $37^{\circ} \mathrm{C}$, with the exception of catalase, which was assayed at $25^{\circ} \mathrm{C}$. The distribution of catalase activity showed a positive skew within each group and logarithmic transformation of the results was required to enable comparison of groups by a parametric method..$^{34}$ For each enzyme the spread within each group was then compared by Bartlett's test of homogeneity of variance. ${ }^{34}$ If the groups were similar in their degree of spread $(p>0.05)$ a standard one way analysis of variance test was used to compare the groups. If differences were found with these preliminary methods then the group contrast was calculated with group means in order to establish the presence of a linear trend with the degree of atrophy or a difference between the pooled alcohol groups and the control group. ${ }^{35}$ If the groups showed significantly non-homogeneous variance, as in the case of lactate dehydrogenase and $\mathrm{Ca}^{2+}$-ATPase, then groups were compared using the non-parametric Kruskal-Wallis one way analysis of variance test. ${ }^{36}$ If this analysis showed significant variance $(p<0.05)$ the groups were compared using a Mann-Whitney test.

\section{Results}

Clinical and morphometric details are summarised in Table 1.

\section{MORPHOMETRY}

Atrophy of type II fibres was found in 33 of 41 patients studied (Fig. 2). Differences between median fibre diameters were evident with a decreasing diameter from the normal alcoholic to the severe atrophy group. This was true for both fibre types,

Table 1 Clinical details and histomorphometric results from muscle biopsy samples

\begin{tabular}{|c|c|c|c|c|c|c|c|}
\hline \multirow[t]{3}{*}{$\begin{array}{l}\text { Patient } \\
\text { groups }\end{array}$} & \multirow[t]{3}{*}{$\begin{array}{l}\text { Type II } \\
\text { atrophy factor }\end{array}$} & \multirow[t]{3}{*}{ No } & \multicolumn{2}{|c|}{ Sex } & \multirow[t]{3}{*}{$\begin{array}{l}\text { Age (yr) } \\
\text { (Mean) }\end{array}$} & \multirow{2}{*}{\multicolumn{2}{|c|}{$\begin{array}{l}\text { Median fibre diameter } \\
(\text { Mean } \pm S E M)\end{array}$}} \\
\hline & & & \multirow[t]{2}{*}{$M$} & \multirow[t]{2}{*}{$F$} & & & \\
\hline & & & & & & Type I & Type II \\
\hline Patient controls & $\begin{array}{l}<150 \text { Men } \\
<200 \text { Women }\end{array}$ & 13 & 8 & 5 & $\begin{array}{l}21-66 \\
(47)\end{array}$ & $60 \cdot 4 \pm 2 \cdot 2$ & $57 \cdot 0 \pm 2 \cdot 2$ \\
\hline $\begin{array}{l}\text { Alcoholic patients- } \\
\text { Normal muscle }\end{array}$ & $\begin{array}{l}<150 \text { Men } \\
<200 \text { Women }\end{array}$ & 8 & 6 & 2 & $\begin{array}{l}37-55 \\
(44)\end{array}$ & ${ }^{*} 63.9 \pm 2.9$ & $\dagger 55 \cdot 6 \pm 2 \cdot 0$ \\
\hline Mild atrophy & $\begin{array}{l}150-600 \text { Men } \\
200-600 \text { Women }\end{array}$ & 22 & 13 & 8 & $\begin{array}{l}30-68 \\
(48)\end{array}$ & ${ }^{*} 56.7 \pm 1.9$ & $\dagger 43.4 \pm 1 \cdot 3$ \\
\hline Severe atrophy & $>600$ Both sexes & 11 & 8 & 3 & $\begin{array}{l}36-66 \\
(52)\end{array}$ & ${ }^{*} 52.5 \pm 1.6$ & $\dagger 36.1 \pm 1.8$ \\
\hline
\end{tabular}

*Decreasing trend with atrophy $(\mathrm{p}<0.05)$.

$\dagger$ Decreasing trend with atrophy $(\mathrm{p}<0.001)$. 
though the percentage drop in median diameter from the normal alcoholic group to the severe atrophy group was much larger for type II fibres (33\%) than for type I fibres $(17 \%)$. The individual histograms for each biopsy constructed for each fibre type generally showed a skewed distribution towards the low diameter end. The distribution of fibre diameters was in no case bimodal.

\section{HISTOLOGY}

Three patients showed changes of acute myonecrosis. Patient 1 , a 41 year old woman, had a type II fibre atrophy factor of 248 and median fibre diameters of 47 (type I) and 35 (type II). Patient 2, a 54 year old woman, had an atrophy factor of 253 and median fibre diameters of 55 and 37 , respectively. Patient 3, a 60 year old man, who also appeared severely malnourished, had an atrophy factor of 1600 and fibre diameters of 48 and 31, respectively. Only one patient showed reduction of myophosphorylase stain and this was in relation to a necrotic fibre. Fibrosis or internalisation of nuclei (greater than $2 \%$ ) was not noted and there was no histological evidence of fibre denervation. ${ }^{24}$

TISSUE BIOCHEMICAL ANALYSIS (Tables 2, 3, 4) Table 2 shows the protein and principal organelle marker enzyme activities in the muscle biopsy samples. Neutral $\alpha$-glucosidase (sarcoplasmic reticulum) and 5'nucleotidase (sarcolemma) activities expressed per $\mathrm{mg}$ protein showed significant differences between the four groups. On further statistical analysis the mean activities of the patient control and the normal alcohol groups were similar whereas those of the three alcohol groups showed a significant and increasing trend with atrophy. $\mathrm{N}$-Acetyl- $\beta$-glucosaminidase activity per $\mathrm{mg}$ protein showed a similar trend, though this was not significant. The pooled results for all alcohol groups, however, showed a significant increase in this enzyme activity compared with patient controls. There were no significant differences in acid phosphatase activities between the various patient groups. None of the above mentioned differences was evident when enzyme activities were expressed per $\mu \mathrm{g}$ DNA.

Catalase activity was distributed in a positive skew fashion with a few samples in each group having very high activities. This could not be related to the type or severity of myopathy or history of alcohol consumption. It may reflect the degree of red cell contamination of the tissue sample. No significant difference in protein to DNA ratio between the groups was found and, although a decreasing trend with the degree of atrophy was evident, this was not significant.

Table 3 shows that the activities of mitochondrial enzyme markers and lactate dehydrogenase did not differ appreciably between the groups. Assays of ATPase activities are shown in Table 4. $\mathrm{Ca}^{2+}$ ATPase activity, both total and azide-resistant, showed a significant reduction per $\mu$ g DNA compared with the other patient groups. The azidesensitive fraction of $\mathrm{Ca}^{2+}$-ATPase did not show significant reductions. Differences were not evident when enzyme activities were expressed per mg protein.

For certain enzymes the mean activity of the group showing acute myopathy was different from the others, but numbers were too small to enable

Table 2 Organelle marker enzyme activities in patient groups.

\begin{tabular}{|c|c|c|c|c|c|c|}
\hline \multirow[t]{3}{*}{$\begin{array}{l}\text { Enzyme } \\
\text { (organelle) }\end{array}$} & \multicolumn{6}{|c|}{$\begin{array}{c}\text { Specific activities } \\
\text { (Mean } \pm \text { SEM for }(n) \text { samples) }\end{array}$} \\
\hline & \multirow{2}{*}{\multicolumn{2}{|c|}{$\begin{array}{l}\text { Patient controls* } \\
\text { (11) }\end{array}$}} & \multicolumn{4}{|l|}{ Alcoholic patients } \\
\hline & & & $\begin{array}{l}\text { Normal } \\
\text { (5) }\end{array}$ & $\begin{array}{l}\text { Mild atrophy } \\
(16)\end{array}$ & $\begin{array}{l}\text { Severe atrophy } \\
\text { (7) }\end{array}$ & $\begin{array}{l}\text { Myonecrosis } \\
\text { (3) }\end{array}$ \\
\hline $\begin{array}{l}\text { Neutral } \alpha \text {-glucosidase }\left(\times 10^{3}\right) \\
\text { (sarcoplasmic reticulum) } \\
5^{\prime} \text { Nucleotidase } \\
\text { (sarcolemma) } \\
\text { N-Acetyl- } \beta \text {-glucosaminidase } \\
\text { (lysosome) } \\
\text { Acid phosphatase } \\
\text { (lysosome) } \\
\text { Catalase (log) } \\
\text { (peroxisome) } \\
\text { Protein/DNA }(\mathrm{mg} / \mu \mathrm{g})\end{array}$ & $\begin{array}{l}\mathbf{a} \\
\mathbf{b} \\
\mathbf{a} \\
\mathbf{b} \\
\mathbf{a} \\
\mathbf{b} \\
\mathbf{a} \\
\mathbf{b} \\
\mathbf{a} \\
\mathbf{b}\end{array}$ & $\begin{array}{l}40.2 \pm 4.4 \\
18.6 \pm 1.5 \\
0.250 \pm 0.031 \\
0.118 \pm 0.022 \\
0.068 \pm 0.006 \\
0.043 \pm 0.003 \\
2.07 \pm 0.23 \\
1.02 \pm 0.12 \\
1.12 \pm 0.13 \\
0.715 \pm 0.126 \\
0.476 \pm 0.039\end{array}$ & $\begin{aligned}+38.3 & \pm 4.7 \\
20.8 & \pm 3.5 \\
+0.223 & \pm 0.038 \\
0.124 & \pm 0.027 \\
\mp 0.076 & \pm 0.010 \\
0.049 & \pm 0.005 \\
2.02 & \pm 0.19 \\
1.02 & \pm 0.13 \\
0.803 & \pm 0.079 \\
0.535 & \pm 0.098 \\
0.530 & \pm 0.083\end{aligned}$ & $\begin{aligned}+51.7 & \pm 3.8 \\
22.3 & \pm 1.6 \\
+0.406 & \pm 0.054 \\
0.186 & \pm 0.027 \\
\ddagger 0.099 & \pm 0.009 \\
0.055 & \pm 0.007 \\
2.20 & \pm 0.24 \\
1.07 & \pm 0.13 \\
0.951 & \pm 0.094 \\
0.532 & \pm 0.081 \\
0.482 & \pm 0.054\end{aligned}$ & $\begin{aligned}+57 \cdot 1 & \pm 8.9 \\
19 \cdot 5 & \pm 2 \cdot 8 \\
+0.470 & \pm 0.067 \\
0.162 & \pm 0.022 \\
\ddagger 0.102 & \pm 0.011 \\
0.053 & \pm 0.005 \\
2.61 & \pm 0.37 \\
0.83 & \pm 0.19 \\
1.28 & \pm 0.17 \\
0.731 & \pm 0.188 \\
0.351 & \pm 0.049\end{aligned}$ & $\begin{array}{l}63.0 \pm 17.0 \\
23.0 \pm 3.2 \\
0.616 \pm 0.061 \\
0.340(2) \\
0.119 \pm 0.046 \\
0.064 \pm 0.003 \\
2.57 \pm 0.46 \\
1.19 \pm 0.11 \\
0.857 \pm 0.246 \\
0.642(2) \\
0.500 \pm 0.098\end{array}$ \\
\hline
\end{tabular}

${ }^{*}$ Control specific activities (protein) are taken from Martin et al ${ }^{25}$

$\dagger$ Increasing trend with atrophy $(\mathrm{p}<0.05)$.

$\ddagger$ Combined alcohol groups increased compared with controls $(p<0.05)$.

$\mathrm{a}=$ specific activities expressed as $\mathbf{m U n i t s} / \mathbf{m g}$ protein.

$\mathrm{b}=$ specific activities expressed as mUnits/ $\mu \mathrm{g}$ DNA. 
Table 3 Organelle marker enzyme activities by patient groups

\begin{tabular}{|c|c|c|c|c|c|}
\hline \multirow[t]{3}{*}{$\begin{array}{l}\text { Enzyme } \\
\text { (organelle) }\end{array}$} & \multicolumn{5}{|c|}{$\begin{array}{c}\text { Specific activities } \\
\text { (Mean } \pm S E M \text { for }(n) \text { samples) }\end{array}$} \\
\hline & \multirow{2}{*}{$\begin{array}{l}\text { Patient controls* } \\
\text { (II) }\end{array}$} & \multicolumn{4}{|c|}{ Alcoholic patients } \\
\hline & & $\begin{array}{l}\text { Normal } \\
\text { (5) }\end{array}$ & $\begin{array}{l}\text { Mild atrophy } \\
(16)\end{array}$ & $\begin{array}{l}\text { Severe atrophy } \\
\text { (7) }\end{array}$ & $\begin{array}{l}\text { Myonecrosis } \\
\text { (3) }\end{array}$ \\
\hline $\begin{array}{l}\text { Malate dehydrogenase } \\
\text { (cytosol and mitochondria) } \\
\text { Glutamate dehydrogenase } \\
\text { (mitochondria) } \\
\text { Succinate dehydrogenase } \\
\text { (mitochondria) } \\
\text { Lactate dehydrogenase } \\
\text { (cytosol) }\end{array}$ & $\begin{array}{lrl}\text { a } & 1160 & \pm 104 \\
\text { b } & 337 \pm 23 \\
\text { a } & 0.473 \pm 0.148 \\
\text { b } & 0.427 \pm 0.121 \\
\text { a } & 9 \cdot 18 \pm 1.72 \\
\text { b } & 2 \cdot 13 \pm 0.49 \\
\text { a } & 184 \pm 18 \\
\text { b } & 74.3 \pm 9.6\end{array}$ & $\begin{array}{c}1110 \pm 200 \\
310 \pm 62 \\
0.329(n=2) \\
0 \cdot 279(n=2) \\
8 \cdot 10 \pm 0.90 \\
3 \cdot 02 \pm 0.38 \\
163 \pm 22 \\
87.4 \pm 11.8\end{array}$ & $\begin{aligned} 1380 & \pm 150 \\
342 & \pm 41 \\
0.385 & \pm 0.070 \\
0.354 & \pm 0.097 \\
6.68 & \pm 0.90 \\
1.61 & \pm 0.25 \\
211 & \pm 26 \\
112 & \pm 14\end{aligned}$ & $\begin{aligned} 1240 & \pm 150 \\
213 & \pm 29 \\
0 \cdot 376 & \pm 0 \cdot 134 \\
0 \cdot 291 & \pm 0 \cdot 039 \\
7 \cdot 72 & \pm 1 \cdot 74 \\
2 \cdot 99 & \pm 1 \cdot 63 \\
161 & \pm 39 \\
58 \cdot 0 & \pm 3 \cdot 1\end{aligned}$ & $\begin{array}{c}1280 \pm 71 \\
405 \pm 9 \\
0.699(2) \\
0.252(2) \\
5.73 \pm 1.62 \\
3.06(2) \\
232 \pm 59 \\
154 \pm 46\end{array}$ \\
\hline
\end{tabular}

${ }^{*}$ Control specific activities (protein) are taken from Martin et al. ${ }^{25}$

$\mathrm{a}=$ specific activities expressed as $\mathrm{mUnits} / \mathrm{mg}$ protein.

$\mathrm{b}=$ specific activities expressed as mUnits/ $\mu \mathrm{g}$ DNA.

conclusive information to be obtained. There was, however, considerably reduced activity of myofibrillary azide-resistant $\mathrm{Mg}^{2+}$-ATPase, in contrast with the $\mathrm{Ca}^{2+}$-ATPase activities, which were not reduced (Table 4). There was also an increase in 5'nucleotidase activity in tissue from patients with acute myopathy (Table 2).

\section{Discussion}

The use of quantitative morphometry has allowed the characterisation of muscle from chronic alcoholics into normal, mild, and severe type II atrophy. The results of this study confirm the finding of an earlier series ${ }^{17}$ that the major histological abnormality of muscle in chronic alcoholics is the presence of a selective atrophy of type II fibres - that is, the fast twitch fibres.

A systematic study of vastus lateralis muscle in normal adult men (aged 22 to 65 years) ${ }^{37}$ has shown that the proportion and mean diameter of type II fibres decreases with age. Such a change in diameter was not evident in type I fibres. Other workers have also reported type II atrophy in elderly subjects. ${ }^{38}{ }^{34}$ The exact mechanism of this change is not known, and it could be related to changing patterns of physical activity, nutritional factors, or endogenous changes of gene expression. The differences in age

Table 4 Organelle marker enzyme activities by patient group

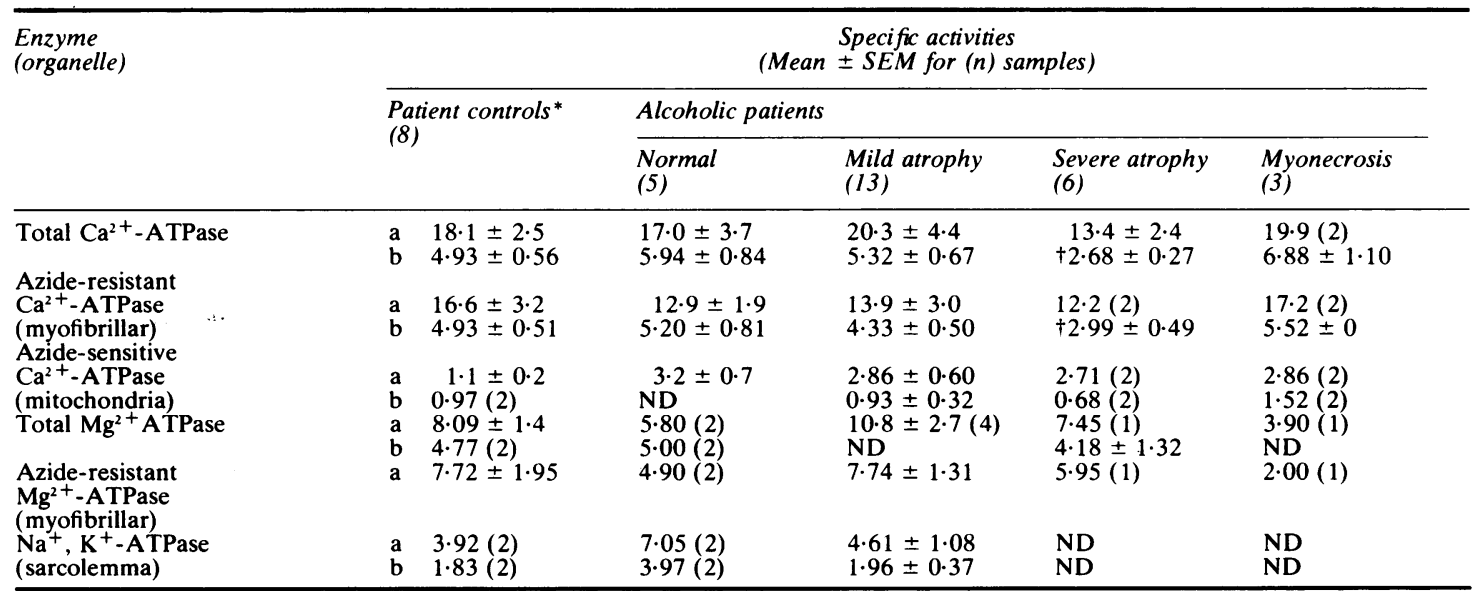

${ }^{*}$ Control specific activities (protein) from Martin et al. ${ }^{25}$

†Significant reduction compared with patient controls and normal alcoholic groups $(\mathrm{p}<0 \cdot 05)$.

$a=$ specific activities expressed $/ \mathrm{mg}$ protein

$b=$ specific activities expressed $/ \mu \mathrm{g}$ DNA.

ND $=$ not determined 
distribution of the groups reported here are small and it would seem unlikely that they would introduce significant age related changes.

The size of both fibre types is smaller in women than men. ${ }^{28}$ In our study the proportion of women in each group was roughly similar and was least in the group with the smallest fibre sizes (Table 1). It seems unlikely therefore that different sex ratios between the groups gave rise to the morphometric differences.

Could physical inactivity explain the findings? Our patients were ambulant and mainly in full time employment. Immobilisation of a limb generally produces preferential type I atrophy, ${ }^{4041}$ but a mixed fibre atrophy has been reported in association with inactivity. ${ }^{42}$

Three patients had changes of myonecrosis, identified by standard histological criteria. Although the finding can only be preliminary, there was a considerable decrease in activity of myofibrillary $\mathrm{Mg}^{2+}$-ATPase in the one patient studied. This finding agrees with previous studies ${ }^{16}$ of an individual patient and of experimentally induced changes in human volunteers and baboons chronically exposed to ethanol. Those studies showed both reduced $\mathrm{Ca}^{2+}$ uptake by sarcoplasmic reticulum in vitro and reduced myosin $\mathbf{M g}^{2+}$-ATPase activity. Although striking ultrastructural abnormalities of the mitochondria and sarcoplasmic reticulum were noted, fibre size was not assessed.

In a previous study of chronic alcoholics ${ }^{18}$ studied within one to two days of an acute debauch, significant reductions in the activities of lactate, malate, and succinate dehydrogenases were reported. Enzyme activities returned to control values within six days. No histological assessment of the biopsies was made, so direct comparison with our patients may not be appropriate. Kiessling et al ${ }^{14}$ found reduced activities of lactate and triose phosphate dehydrogenases in biopsies from chronic alcoholics. They also reported type II fibre atrophy in the group as a whole and were able to correlate the specific activities of those enzymes with the reduced amount of fast twitch glycolytic, type II fibres. They also showed reduced mitochondrial volume fraction and reduced activity of cytochrome oxidase in these patients, but did not report type I fibre atrophy. We found some atrophy of type I fibres but failed to confirm any reduction in four mitochondrial enzyme activities in the muscle biopsies.

The major enzyme abnormality, particularly when the results were expressed/ $\mu \mathrm{g}$ DNA, was the increasing reduction in myofibrillary $\mathrm{Ca}^{2+}-\mathrm{ATPase}$ with increasing atrophy. The activity of this enzyme is higher in type II than type I fibres. ${ }^{43}$ Thus the reduc- tion may reflect the selective loss of contractile elements from type II fibres. The other abnormalities found in our studies may also be explained on the basis of a selective atrophy of myofibrillary protein, with relative preservation of other cell protein, and specifically a preservation of the sarcolemma and sarcoplasmic reticulum so that enzyme activities associated with these organelles show an apparent rise when expressed in terms of protein content but not in terms of DNA content. This underlines the importance of using a suitable reference parameter for the expression of enzyme activities. In this type of study, wet and dry weight or tissue protein will all tend to change in the same direction as myofibrillary atrophy and thus possibly obscure significant changes.

The increased activity of one lysosomal enzyme, $\mathrm{N}$-acetyl- $\beta$-glucosaminidase, without significant change in the other lysosomal marker enzyme is of doubtful pathological importance. Increased lysosomal enzyme activity has previously been reported in human muscle dystrophy ${ }^{44}$ Neurogenic atrophy of human muscle is associated with increased numbers of lysosomes ${ }^{45}$ and in experimental animals with an increased activity of acid hydrolases. ${ }^{46}$ The normal catalase value also contrasts with the increased activity of this enzyme recently reported in muscular dystrophy ${ }^{47}$ and in the type II atrophy caused by starvation or denervation of rat skeletal muscle. ${ }^{48}$ The observed atrophy in our patients may therefore have a different pathogenic mechanism from type II atrophy occurring in other conditions.

These findings suggest that gross organelle damage is not involved in the pathogenesis of the muscle damage associated with chronic alcoholism. The selective atrophy of fast twitch fibres is of interest and suggests that further attention should be paid to the physiological role and metabolic properties of these fibres, and the effects of ethanol thereon.

We are grateful to Mr P Ward for technical assistance with histology, to Ms C Dore for statistical advice, and to Ms R Greensted for secretarial assistance.

\section{References}

' Report of the Special Committee of the Royal College of Psychiatrists. Alcohol and alcoholism. London: Tavistock Publications, 1979.

2 Jariwalla AG, Adams PH, Hore BD. Alcohol and acute general medical admission to hospital. Health Trends 1979;1:95-7.

3 Jarman CMB, Kellet JM. Alcoholism in the general hospital. Br Med J 1979;ii:469-72.

${ }^{4}$ Lieber CS, Jones DP, Decarli LM. Effects of prolonged ethanol intake: production of fatty liver despite adequate diets. J Clin Invest 1965;44:1009-21. 
s Jackson J. On a peculiar disease resulting from the use of ardent spirits. N Engl J Med 1822;XI:351-3.

- Rubin E. Alcholic myopathy in heart and skeletal. $N$ Engl J Med 1979;301:28-33.

' Geller SA, Rubin E. The effect of alcohol on striated and smooth muscle. In: Lieber CS, ed. Metabolic aspects of alcoholism. Lancaster: MTP Press Ltd, 1977:187-213.

${ }^{*}$ Spargo E. Alcohol and muscle disease. Br J Alcohol Alcoholism 1981;16: 124-34.

"Martin FC, Slavin G, Levi AJ. Alcoholic muscle disease. Br Med Bull 1982;38:53-6.

"' Douglas RM, Fewings JD, Casley-Smith JR. West RF. Recurrent rhabdomyolysis precipitated by alcohol. A case report with physiological and electron microscopic studies of skeletal muscle. Aust Ann Med 1982;15:251-6.

" Klinkerfuss G, Bleisch V, Dioso MM, Perkoff GT. A spectrum of myopathy associated with alcoholism. II Light and electron microscopic observations. Ann Int Med 1967;67:493-510.

12 Kahn LB, Meyer JS. Acute myopathy in chronic alcoholism. A study of 22 autopsy cases, with ultrastructural observations. Am J Clin Pathol 1970:53:516-30.

${ }^{13}$ Fisher ER, Punterri AJ, Jung Y, Corredor DG, Danowski TS. Alcoholism and other concomitants of mitochondrial inclusions in skeletal muscle. Am J Med Sci 1971;214:97-106.

${ }^{14}$ Kiessling KH, Pilstrom L, Karlsson J, Piehl K. Mitochondrial volume in skeletal muscle from young and old, untrained and trained healthy men and from alcoholics. Clin Sci 1973;44:547-54.

is Chiu LA, Neustein LH, Munsat TL. Tubular aggregates in subclinical alcoholic myopathy. Neurology (NY) 1975;25:405-12.

${ }^{16}$ Rubin E, Katz AM, Lieber CS. Stein EP, Puszkin S. Muscle damage produced by chronic alcohol consumption. Am J Pathol 1976;83:499-516.

17 Hanid A. Slavin G, Muir W, et al. Fibre type changes in striated muscle of alcoholics. J Clin Pathol 1981;34:991-5.

i* Suominen H, Forsberg S, Heikkinen E, Osterback L. Enzyme activities and glycogen concentration in skeletal muscle in alcoholism. Acta Med Scand 1974:196:199-202.

"Kiessling KH, Pilstrom L, Bylund AC, Piehl K, Saltin B. Effects of chronic ethanol abuse on structure and enzyme activities of skeletal muscle in man. Scand $J$ Clin Lab Invest 1975;35:601-7.

2 Peters TJ. Investigation of tissue organelles by a combination of analytical subcellular fractionation and enzymic microanalysis: a new approach to pathology. J Clin Pathol $1981 ; 34: 1-12$

" Peters TJ, Wells G, Oakley CM, et al. Enzymic microanalysis of endomyocardial biopsy specimens from patients with cardiomyopathies. Br Heart J 1977;39: 1333-9.

22 Fitchett DH, Wells G, Peters TJ. Analytical subcellular fractionation of human heart: a comparison of left and right ventricle with hypertrophic obstructive myopathic tissue. Cardiovasc Res 1979; 13:532-40.

${ }^{23}$ Fitchett DH, Scott J, Stephens HR, Peters TJ. Myocardial subcellular fractionation studies on cardiomyopathic Syrian hamsters. Cardiovasc Res 1979;13:260-8.

${ }^{24}$ Neerunjun JS, Dubowitz V, Peters TJ. Analytical subcellular fractionation and enzymic analysis of dystrophic mouse skeletal muscle. Biochem Soc Trans 1978;6:1266-8.

¿s Martin FC, Levi AJ, Slavin G, Peters TJ, Analytical subcellular fractionation of normal human skeletal muscle by sucrose density gradient centrifugation. Eur $J$ Clin Invest 1983;13:49-56.

${ }^{26}$ Edwards RHT, Young A, Wiles M. Needle biopsy of skeletal muscle in the diagnosis of myopathy and the clinical study of muscle function and repair. $N$ Engl J Med 1980;302:261-70.

¿7 Slavin G, Sowter C, Ward P, Paton K. Measurement of striated muscle fibre diameters using interactive computer aided microscopy. J Clin Pathol 1982;35: 1268-71.

${ }^{2 *}$ Brooke MH, Engel WK. The histographic analysis of human muscle biopsies with regard to fibre types. I Adult male and female. Neurology (NY) 1969;19:221-33.

${ }^{24}$ Dubowitz V, Brooke MH. Muscle biopsy: a modern approach. New York: Saunders, 1973.

30 Smith GD, Peters TJ. Analytical subcellular fractionation of rat liver with special reference to the localisation of putative plasma membrane marker enzymes. Eur $J$ Biochem 1980;104:305-11.

"Schacterle GR, Pollack RL. A simplified method for the quantitative assay of small amounts of protein in biologic material. Anal Biochem 1973;51:654-5.

${ }^{32}$ Lowry OH, Rosebrough NJ, Farr AL, Randall RJ. Protein measurement with folin-phenol reagent. J Biol Chem 1951; 193: $265-75$.

${ }^{3}$ Kapuscinksi J, Skoczylas B. Simple rapid fluorometric method for DNA microassay. Anal Biochem 1977;83:252-7.

${ }^{34}$ Armitage P. Statistical methods in medical research. Oxford: Blackwell Scientific Publications, 1971.

3s Siegel S. Nonparametric statistics. Tokyo: McGraw-Hill, 1956.

${ }^{36}$ Cochran WG, Cox GM. Experimental design, 2nd ed. New York: John Wiley, 1957:70.

${ }^{37}$ Larsson L. Morphological and functional characteristics of the aging skeletal muscle in man. A cross-sectional study. Acta Physiol Scand 1978; Suppl 457:33.

${ }^{3 *}$ Engel WK. Selective and nonselective susceptibility of muscle fibre types. Arch Neurol (Chic) 1970;22:97-117.

${ }^{34}$ Tomonaga M. Histochemical and ultrastructural changes in senile human skeletal muscle. J Am Geriatr Soc 1977;3:12531.

4) Edström L. Selective atrophy of red muscle fibres in the quadriceps in long standing knee-joint dysfunction injuries to the anterior cruciate ligament. J Neurol Sci 1970;11:551-8.

${ }^{41}$ Young AA, Häggmark T, Brooke MH. Cylinder or mobile cask brace after knee ligament surgery: a clinical analysis and morphological and enzymatic studies of changes in the quadriceps muscle. Am J Sports Med 1979;7:48-50.

${ }^{42}$ Sirca A, Sûsec-Michieli M. Selective type II fibre muscular atrophy in patients with osteoarthritis of the hip. J Neurol Sci 1980; 40: 149-59.

${ }^{43}$ Thorstensson A, Sjodiu B, Tesch P, Karlsson J. Actomyosin ATPase, myokinase, CPK and LDH in human fast and slow twitch muscles. Acta Physiol Scand 1977;99:225-9.

${ }^{44}$ Weinstock IM, Iodice AA. Acid hydrolase activity in muscular dystrophy and denervation atrophy. In: Dingle JT, Fell HB, eds. Lysosomes in biology and pathology, vol I. London, 1969:450-68.

"s Shafia SA, Milhorat AT, Goryck MA. Fine structure of human muscle in neurogenic atrophy. Neurology (NY) 1967;17:934-48.

${ }^{46}$ Pollack MS, Bird JWC. Distribution and particle properties of acid hydrolase in denervated muscle. Am $J$ Physiol 1968;215:716-22.

${ }^{47}$ Kar NC, Pearson CM. Catalase, superoxide dismutate, glutathione reductase and thiobarbituric acid - reactive products in normal and dystrophic human muscle. Clin Chim Acta 1978;94:277-80.

48 Stauber WT, Bird JNC, Schottelius BA. Catalase: An arythmetric indicator of the degree of muscle wasting. Exp Neurol 1979;55:381-9.

Requests for reprints to: Professor TJ Peters, Division of Clinical Cell Biology, MRC Clinical Research Centre, Watford Road, Harrow, Middlesex, England. 